\title{
非粘着性塗料
}

徳田 哲男*, 寺川 騏一郎*

\author{
Nonstiky Paint
}

Tetsuo TOKUDA*, Kiichiro TERAKAWA**

付いては困るものを付かせないための塗料を「非粘着性塗料」と定義 づけ, その非粘着性, 離型性機能と効果を概略的に解説し, 一部を理論 づけた。またその用途も, 現在, 市場化されているものの多くは常乾型 で, 家庭用日常品から工場などの大型プラントに及んでいる。

\section{1. 污れと付着物}

現在の便利化された文明社会で, 日常生活でも 職場の中でも, 污れあのや付着堆積物の清掃・除 去作業は職業化されているあのああるほどであり， 家庭の主婦から工場の技術者に至るまで, 污れや 付着物に対する悩みの夕ネは多い。

このやっかいなものは, 付着物, 付着の仕方, 付着してからの様相がさまざまであり, 簡単に払 って落とせるものから，思いの外に時間と手間が かかるあのまであり, 除去作業に人手や動力がか かり，その作業はなかなかばかにならない。
乙の付着現象の中で, 最む日常的なゴミやチリ ・ススなどの微細物の付着は, 主に静電気的な作用 に起因するのであるが，乙れは美観や機能を損ね るばかりでなく，チリやホコリがさらに污物や湿 気を呼び，エアコン・内燃機関などの網目に目づ まりや熱伝導阻害を起乙したし，ホッパーなどに ブリッヂ現象を起てしたりして，トラブルや事故 を引き起乙す原因ともなる。そのため，定期的な 点検を行い，その対処や対策に，日常的な配慮を 怠ることはできない。

これらの付着物と付着の仕方は被着体の材質と 表面の形状・状態によっても様々である。付着の 様相をごく常識的に類別化すると，表１のように

表 1 付 着 の 様 相

\begin{tabular}{|c|c|c|c|c|}
\hline \multicolumn{2}{|c|}{ 付着の形態 } & 付 & の 現 象 & 付 着 \\
\hline 吸 & 着 & 水滴, チリ, スス, 灰, 微粉体 & $\begin{array}{l}\text { 綱目, 多孔質材などの混入，目 } \\
\text { 詰り, ホッパー等のブリッシ現象 }\end{array}$ & 静電気的作用 \\
\hline 粘 & 着 & $\begin{array}{l}\text { 油煙, タール, ワックス, スラッヂ } \\
\text { ポリマースケール, シロップ }\end{array}$ & $\begin{array}{l}\text { ぬれ } \rightarrow \text { 浸透拡散 } \\
\text { キレッ, 孔陥入 }\end{array}$ & $\begin{array}{l}\text { フアン・デル・ワールスカ（2 } \\
\text { 次結合力） 油性結合 }\end{array}$ \\
\hline 接 & 着 & コールタール, ゴム, レジン & $\begin{array}{l}\text { ぬれ } \rightarrow \text { 投錨的結合 } \\
\text { ブロッキング }\end{array}$ & $\begin{array}{l}\text { 炛学的結命力 ( } 1 \text { 次結合力 ) } \\
\text { 分 散 }\end{array}$ \\
\hline 固 & 着 & $\begin{array}{l}\text { 吡, スラリー, ピッチ，燃焼 } \\
\text { 残椬 }\end{array}$ & $\begin{array}{l}\text { セメントの固化 } \\
\text { 血液の䧳結, 焼結 }\end{array}$ & $\begin{array}{l}\text { 残渣物の } 1 \text { 次および } 2 \text { 次結合 } \\
\text { 力の複合 }\end{array}$ \\
\hline
\end{tabular}

* 持田商工(株) 第 2 営業部

干101 東京都午代亩区岩本町 2-10-12

$03-861-6161$

**持田商工侏 川口工場研究室

干333 埼玉県川口市前川3-20-22

$0486-68-2111$
*Mochida Co., Ltd.

10-12, Iwamoto-cho 2-chome, Chiyoda-ku, Tokyo 101

**20-22, Maekawa 3-chome, Kawaguchi-shi, Saitama 333 
てれをまとめることができる。

てれらの付着物を付かなくさせる方法として， 表面処理的には，1つに被着体の表面をぬれない ようにさせる。浸透させないようにする。付着物 をすべりやすくさせる。帯電させないようにさせ る。さらに凸凹をつけて, 接触面積を小さくさせ ることである。

そのための一般的に通常行われている方法とし ては，

（1）フッ素樹脂・シリコーン樹脂，あるいは乙 れらのゴム質系のトップコート。又は乙れを主バ インダーとした塗料のコーティング。あるいはこ れらのオイル・グリース・ペーストなどの一次的 な表面処理剂の塗布

（2）ガラスビース・骨材などの粉粒物入りの塗 剂の吹付けによる一様な凸凹面の形式。

(3) 乙れらの組成からなるシートの貼着。又は マスキングテープの貼付け。

（4）熱可塑性樹脂を主剂とし，易はく離性皮膜 を形成するもののトップ・コート。

てのうち(1)と(2)から, 硬化塗膜を形成して, 本 題の塗料又はプラスチック・コーティングとして 得るものについて, こてで非粘着塗料と定義づけ て, 非粘着性の機能と因子について，その概略を 私見をまじえながら説べてみることにする。

\section{2. 塗料の非粘性の機能と諸因子}

現在, この種の塗料・コーティング剂として, 市場に広く供せられているものとして，フッ素樹 脂系・シリコーン樹脂系があり，使用され，応用 されている範囲む, 一般家庭から工場の作業・生 産管理面まで多種・多岐にわたっている。

てれらの樹脂の非粘着性因子を分析すると, 以 下の表面物性の 1 つ又は 2 つ以上が複合し, 相乗 して機能化されている。

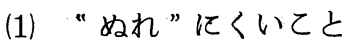

水や油, 溶剂など液体に表面がぬれ難いこと（付 着ぬれ・拡散ぬれ)，浸み込みにくいこと（浸透 ぬれ），すなわち疎水性・撥油性であることであ る。乙れを数值に示したのが表 2 である。疎水性 を表わす数量として, 接触角と同様, 臨界表面張
力 $\left(r_{c}\right)$ あよく用いられている数值であり, 接触 する液体の表面張力を $\mathrm{r}$ とすると, $\mathrm{r}$ が $\mathrm{r}_{\mathrm{c}}$ より 大きい液体には接触する表面はぬれにくいという 関係があり，テフロン・シリコーン樹脂は最もぬ れにくいことがわかる。乙のことは樹脂の表面層 の分子構造に関係があり，ポリマー表面の置換基 にフッ素系（例えばトリフロロメタンなど），メ チル・ベンゼン基がつくと林くく，水酸基・ 酢酸基などのあるあのは一般にぬれやすく，ビニ ール基・塩素基は，その中間位置している。

表面張力に対して，ぬれようとする働きを表わ す物性単位として溶解度パラメーター（ S P ）が あるが，S P 值は分子団の凝集エネルギーと考え られ，次式によって計算される。

$$
\begin{aligned}
& \mathrm{LA}=(\mathrm{H}-\mathrm{RT}) / \mathrm{V} \quad(\mathrm{cal} / \mathrm{cc}) \\
& \mathrm{S} \cdot \mathrm{P}=\sqrt{\mathrm{LA}}(\mathrm{cal} / \mathrm{cc})
\end{aligned}
$$

（LA：凝集エネルギー， $\mathrm{R}$ ：気体定数， $\mathrm{V} ： モ$ ル容積, $\mathrm{T}$ : 絶体温度 )

$\mathrm{S} \cdot \mathrm{P}$ 值の大きいほどよく親和し, 接着しやすい ことが立証されており, 表示の数值はフッ素樹脂 ・シリコーン樹脂は $\mathrm{S} \cdot \mathrm{P}$ 值は最も小さく, 接着し 難く非粘着性であることを示している。

又, 乙の凝集エネルギーすなわち接着力（付着 ぬれ）は，次式であ表わされる。

$$
\mathrm{LA}=\mathrm{r}_{\mathrm{c}}(1+\cos \theta)
$$

同じ表面張力 $\mathrm{r}_{\mathrm{c}}$ を有する液体では接触角 $\theta$ が 大きいほど，凝集エネルギーが小さくなり，その 液状物は表面から離脱しやすいととになる。表示 の接着力の值はこれらのプラスチック・フイルム にエポキシ樹脂系接着剤を接着し，その剪断はく 離強さを示したものである。

(2) すべりやすくさせる

塗膜などの表面のすべりやすさ（潤滑性）は, バインダー固有の潤滑性と顔料など配合剂の表面 露出濃度に依存する。また温度・湿度, それにか かる物質荷重などが影響する。ポリマーのすべり やすさ, 滑性もまた化学構造 (平均重合度, 置換 基・立体規則性, 分枝の割合等) に関連し, テフ ロンやエチレン・プロピレンのような非極性モノ マーは分子間力が非常に弱く, ポリマーの分子凝 集が小さく滑性がよい。乙れに対して塩化ビニー 
表 2 各種ポリマーの表面特性

\begin{tabular}{|c|c|c|c|c|c|c|}
\hline & $\begin{array}{c}\text { 接触角 (水) } \\
\theta \text { (度) }\end{array}$ & 動摩擦係数 & $\begin{array}{l}\text { 臨界表面張力 } \\
\mathrm{r}_{\mathrm{c}}(\mathrm{dyne} / \mathrm{cm})\end{array}$ & $\begin{array}{l}\text { 溶解度パラメーター } \\
\left.\text { S P ( } \text { ( cal / cc }^{1}\right)\end{array}$ & $\begin{array}{l}\text { 接 着 力 } \\
\left(\mathrm{kg} / \mathrm{cm}^{2}\right)\end{array}$ & $\begin{array}{l}* 1 \\
2)\end{array}$ \\
\hline ポリ 4 -フッ化エチレン & 115 & 0.04 & 18 & 6.2 & 25 & \\
\hline ポリフッ化ビニール & $72 \sim 75$ & 0.30 & 28 & - & 95 & \\
\hline ポリジメチルシロキサン & $90 \sim 110$ & & 24 & 7.3 & - & \\
\hline ポリエチレン & 88 & 0.33 & 31 & 7.9 & - & \\
\hline ポリスチレン & 78 & & 33 & 8.9 & 80 & \\
\hline ポリ塩化ビニール & 68 & 0.45 & 39 & 9.6 & 130 & \\
\hline ナイロン 66 & 77 & $0.50 * 2$ & 46 & 13.1 & - & \\
\hline
\end{tabular}

$※ 1$ エポキシ樹脂接着剤（表面張力 $50 \mathrm{dyne} / \mathrm{cm}$

※2 湿度による変化が大である。

ル・酢酸ビニールの様な有極性モノマーは分子間 力が影響し，すべり難い。乙れを摩擦係数として 数值化した表 2 から，接触角との間に相関性のあ るととがわかる。すなわち接触角の大きいほよ゙， 摩擦係数が低い。

(3) 帯電させないようにさせる

帯電のしやすさと, 実際の静電障害（吸着・凝 着）との関係は，ほぶ一致した傾向がある。

たとえば検体を屋外に長時間暴露し，污染の程 度を調べてみると, 静電気量の多いむの, 固有抵 抗値の高いものほど污染の程度が大きい。大体の 目安として, $10^{15} \Omega \cdot \mathrm{cm}$ 以上の電気抵抗のむのは きわめて污染されやすく, $10^{9} \Omega \cdot \mathrm{cm}$ 以下ではほと んよ゙障害はなく，その中間では外的条件しだいで， トラブルを発生する可能性があるということが経 験的に知られている。

（4）凸凹面を形成させる

理論的には，表面を凸凹面（鋭角的であるほよ゙ よい）にし，不均一層とすることにより，ぬれに くい面はますますぬれにくくなり，ぬれやすい面 はますますぬれやすくなる。又，界面に気泡を含 ませると，よりぬれにくくなるという関係がある。 このことは自然界の動・植物の羽根や枝葉などの 物の形や機構のなかからあ撥水や污染防止のしく みをくみとることができる。

\section{3. 塗料に非粘着性・離型性を与える素材}

これまでの「非粘着コーティング剂」は主とし て，フッ素樹脂・シリコーン系樹脂のワニスの非 粘着性・離型性・撥水性などの固有の特性を応用 したものである。テフロン加工・フッ素樹脂ライ ニング, シリコーン処理などの各称で知られてい るが，フッ素樹脂は金属面などに直接に付着し難 いので，金属面などに先ずプライマーを被覆し， 次いでその上にフッ素樹脂を被覆するという $2 工$ 程を要するのみならず, 焼付け加熱処理を行うな よ゙, 特別な加工装置・設備を熟練者の経験を要し, かつ基材の材質・形状・大きさ等々と制約がある。 これに対して「非粘着性塗料」は，乙の $3 \sim 4$ 年 の間に市場に出てきたあのであるが，塗装施工が 一般の塗料と同様の使いやすさであり, 常乾型で あるところからその用途も広範となり, 将来性む 有望であると考えられる。

非粘着性塗料のワニスのベースとしては, 前述 の常乾タイプのフッ素樹脂・シリコーン系樹脂が 主に用いられており，乙れにブロッキング防止剤 ・離型性付与剂としてのフッ素またはシリコーン 系オイル・酸アミドなどのそれぞれの特性を塗膜 の表面層に与えながら，金属・プラスチック・セ ラミックなどの被塗材との密着性と, 塗膜として の防食性・物理特性をバランスよく保持させて, 配合設計したあのであり, 素材によっては, プラ イマーの処理を必ずしも必要としない。

ブロッキング防止剤・離型剂としては一般的で 
あるフッ素系オイル・シリコーン系オイルは表面 張力が通常のオイルに比べて非常に小さく, ジメ チル・シリコーンオイルの表面張力は $500 \mathrm{cs}$ 以上 で 21 dyme /cmである。乙の表面張力が小さいと いうことは, 表面エネルギーが小さいてとを示し ており, 撥水性・離型性等に優れている。

また, ジメチル・シリコーンオイルで処理した ガラス板の対水接触角は約 $103^{\circ}$ で, パラフィンの 值とほぶ等しく, 塗膜表面にブリ一ドして拡がり やすく, きわめて薄い膜層を形成する。有機質の 各種オイル・ろう・脂肪族アミドなどのブロッキン グ防止性・離型性は, 表面層に存在する官能基の 密度と種類, ブリードしたものの混成されたm. p. に依存する。

てれに対して, 雲母やタルク・黒鉛・カーボン ブラック・珪藻土類などの無機顔料は, 潤滑性, 帯電防止性を付与し, 表面を粗面にすることで付 着物との接触面積を少なくさせる。ただし, フィ ルムなどの表面の光学的性質を低下させず, 微細 な凸凹をつくるためには $1 \sim 6 \mu \mathrm{m}$ 程度の粉末で あるてとが必要とされている。

これらの無機質顔料の親水性・吸湿性を改良し, 撥水性を付与し，乙れを持続させるためにシリコ ーン系のカップリング剤で処理したり，フッ素系 の表面処理剤を添加するなどの方法もとられてい る。

\section{4. 非粘着性塗料「 T Tコート」}

$「 \mathrm{~T} T コ ー ト 」 は$ 弊社の商品登録出願中の商品 名であり, 非粘着性・撥水性を主な特長とした常 温硬化型の塗料の名称である。

てれまでのべた異物の付着によってひき起てさ れる様々な形の污染や污損, 機械・装置等の機能 低下，障害等を防ぎ，乙れによって作業工程の省 力化にも役立てるととを目的としたあのである。

塗料素材はシリコーン樹脂, 変性シリコーン樹 脂をべースとして，乙れに表面処理した骨材・顔 料・シリコーン系オイル, 界面活性剂等を配合し 組み合せることにより, 塗膜に非粘着性・離型性

・潤滑性・撥水性などの特性を与えている。

塗装は特別な装置・器具等を要せず, 常乾型で あるので, 屋外の大型プラント・構造物・施設等 にも簡単な下地処理で施工できる。又, 非粘着性 塗料であるのにかかわらず，表示のように密着・ 被着できる被塗材が各種広範である。

以下彆社の非粘着性塗料の数品種について, 概 略を紹介し，参考に供したい。

(1) E S - 2

$\mathrm{E} \mathrm{S}-2$ は非粘着性と撥水性を特長とする T T コートの標準品である。

耐熱・耐寒性にも優れ $-60^{\circ} \mathrm{C} \sim 120^{\circ} \mathrm{C}$ の乾熱・

表3 TTコート・ES - 2 の各種被塗材への密着性

\begin{tabular}{|c|c|c|c|c|c|c|c|}
\hline 素 & 材 & \multirow{2}{*}{$\begin{array}{l}\text { 表面調整 } \\
\text { 標準塗装 }\end{array}$} & $\begin{array}{c}\text { 判 定 } \\
\bigcirc^{-} \\
\bigcirc\end{array}$ & \multicolumn{2}{|c|}{ 素 } & 表面調整 & 判 定 \\
\hline 金 & \begin{tabular}{l} 
鉄 \\
ステンレス・スチール \\
アル ミ ニ ウ \\
真 \\
\multicolumn{1}{c}{ 銅 $^{\text {鍮 }}$}
\end{tabular} & & $\begin{array}{c}\bigcirc^{\cdot} \\
\bigcirc \\
\triangle \rightarrow 0 \\
\bigcirc \\
\triangle \rightarrow \bigcirc\end{array}$ & $\begin{array}{l}\text { プ } \\
\text { ラ } \\
\text { ス } \\
\text { チ }\end{array}$ & $\begin{array}{l}\text { アクリル 樹脂 } \\
\text { ポリカーボネート } \\
\text { ポリエステル } \\
\text { ナイロン } 12 \\
\text { ポリプロピレン }\end{array}$ & $\begin{array}{l}\text { 標準塗装 } \\
\text { 仕様による }\end{array}$ & $\begin{array}{l}0 \\
0 \\
0 \\
0 \\
\times\end{array}$ \\
\hline 属 & 亜＼cjkstart鉛 & & $\begin{array}{l}\triangle \rightarrow 0 \\
x \rightarrow \triangle\end{array}$ & ク & $\begin{array}{c}\prime \prime \\
\text { 硬質塩化ビニール }\end{array}$ & $\begin{array}{l}\text { コロナ処理 } \\
\text { マット加工 }\end{array}$ & $\begin{array}{c}x \rightarrow \triangle \\
\bigcirc\end{array}$ \\
\hline & $\begin{array}{ccr}\text { ブ } & \text { リ } \\
\text { ク ロムめっき }\end{array}$ & & $\begin{aligned} \Delta & \rightarrow 0 \\
& \times\end{aligned}$ & $\begin{array}{l}\text { 木 } \\
\text { 材 }\end{array}$ & $\begin{array}{lrrr}\text { 未 } & \text { 加 } \text { 木 } & \text { 材 } \\
\text { 合 } & & \text { 板 }\end{array}$ & 乾燥, 脱脂 & $\begin{array}{l}0 \\
0\end{array}$ \\
\hline 材 & $\begin{array}{lllll}\text { コ } & \text { ク } & リ & - & \text { r } \\
\text { ス } & レ & - & \text { ト } \\
モ & ル & \text { タ } & \text { ル } \\
\text { 自 } & \text { 然 } & \text { 石 } \\
\end{array}$ & 同上 & $\begin{array}{l}0 \\
0 \\
0 \\
0\end{array}$ & ゴ & $\begin{array}{l}\text { エポキシゴム } \\
\text { ウレタンゴム } \\
\text { 他の一般合成ゴム }\end{array}$ & $\begin{array}{c}\text { 機械研磨 } \\
\text { 脱 脂 }\end{array}$ & $\begin{array}{l}\bigcirc \\
\triangle \\
\times\end{array}$ \\
\hline
\end{tabular}

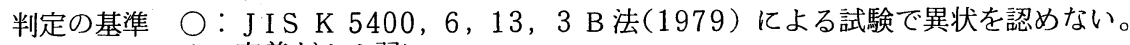
$\triangle$ : 密着がやや弱い

$\times$ : 密着が不充分, 又は不良である。

$\triangle \rightarrow \bigcirc$ : 専用プライマー処理によって素材への密着性が向上する。 
表 $4 \mathrm{ES}-2$ の塗膜の非粘着性状

\begin{tabular}{|c|c|c|c|c|c|c|}
\hline \multirow{6}{*}{$\begin{array}{l}\text { 上塗 塗 料 } \\
\text { はく離 性 }\end{array}$} & \multirow{2}{*}{\multicolumn{2}{|c|}{$\begin{array}{c}\mathrm{ES}-2 \text { クリアー } \\
1 \text { 回 }\end{array}$}} & \multicolumn{2}{|c|}{ ES - 2 各色 } & \multirow{6}{*}{ 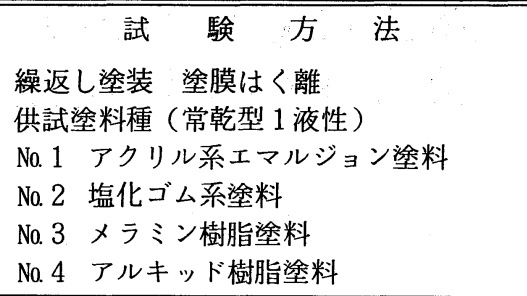 } & \multirow[t]{6}{*}{ 備 考 } \\
\hline & & & 5 回 & 10回 & & \\
\hline & No. 1 & 0 & 0 & 0 & & \\
\hline & №. 2 & 0 & 0 & 0 & & \\
\hline & №. 3 & 0 & $\triangle$ & $x$ & & \\
\hline & №. 4 & 0 & $x$ & & & \\
\hline \multirow{2}{*}{$\begin{array}{l}\text { 粘着テープ } \\
\text { はく離抵抗 }\end{array}$} & 1 回 & 5 回 10 回 & 1 回 & 5回 10回 & \multirow{2}{*}{$\begin{array}{c}\text { ※感圧粘着テープの繰返し粘着はく離試験 } \\
20{ }^{\circ} \mathrm{C} \text {, 湿度 } 60 \%\end{array}$} & \\
\hline & & $\begin{array}{l}50 \quad 60 \\
\mathrm{~g} / 6 \mathrm{~mm}\end{array}$ & 10 & $\begin{array}{r}20 \\
g / 6\end{array}$ & & \\
\hline ハリ紙貼着試験 & \multicolumn{2}{|r|}{0} & \multicolumn{2}{|r|}{0} & 耐候性試験 & \\
\hline
\end{tabular}

※試験機器：オートグラフィーIS-500 (島津製作所)

供試テープ：ニットポリエステル粘着No 31 B 6 mm幅 (Lot 9002506)

試験機の引張り速度：100 mm/min

テープの圧着条件：加重 $2 \mathrm{~kg}$, 加圧ロール速度 1 往復 / $\mathrm{min}$,

圧着ロール幅 $45 \mathrm{~mm}$

冷寒条件下では非粘着性等の特性にほとんど変化 がなく, 耐磨耗性・耐衝撃性などの物理特性にも 異状がない。基材への処理方法・密着性について は表 3 を，非粘着特性は表 4 を参照されたい。

なお, 硬化した塗膜面は人畜無害であり, 食品 等が直接ふれる箇所にあ使用し得る。（厚生省第 20 号試験に合格）

\section{(2) $\mathrm{E} \mathrm{S}-2 \cdot \mathrm{F}$}

主として電柱・歩道橋など, 屋外の構造物の八 リ紙防止用として開発したあのである。

ペーストに配合されたフッ素樹脂粒状物は, 塗 膜に一様の微凸凹を形成させ, 塗膜の非粘着性と あいまって, 貼付されたポスター等の離脱を容易 ならしめるのに有効である。

(3) $\mathrm{S}-1$

一液性・速乾性であるので使いやすく, 非粘着 性・離型性・撥水性 優れた透明な硬化皮膜を形 成する。電気絶縁性・耐候性・耐熱性す良好で, 黄変・光沢低下などの劣化を起乙さない。防水・防 湿コーティング, 貼紙などの貼着防止, 粘着・接 着性物質の付着防止用トップコートとしての用途 がある。加熱・加温することにより, 皮膜硬度は 向上し, 耐薬品性屯発揮する。又, 薄塗り ( $5 \mu \mathrm{m}$ 以下)するてとにより，CR・SBR 等の合成ゴム に対してあ良く接着する様になり, フレキシブル 性を保つ。

\section{(4) S R}

S R は,ゴム弾性に富んだ常乾型 2 液性シリコ
一ン変性塗料である。防食性・耐候性にあ優れ, アルカリ性雾囲気下に良く耐えること屯特長の 1 つである。塗膜はフレキシブル性があるので, 紙 ・フエルト・織布・発泡体などの柔質・含浸性の あのから, 石材などと接着できる基材が多く, 簡 単な素地調整で塗装施工できる。ただし, ゴム素 には専用プライマーを必要とする。

\section{5. おわりに}

種々様々な付着物全般を分類化するなり，定義 づけることはある程度できても, 複合されたその 挙動を理論づけることは, 最も日常的な積雪や 水の付着一つをとり上げてむ, 著者の乏しい知識 では,むづかしいととである。

「非粘着性塗料」は物の表面に塗装することで 付着物が付かないか, 又は自然離脱ないし除去が 容易である塗料の名称であるとした。一応の概念 的なあのを著者のたずさわる職場のデスクで書い てみた。何らかつ参考になれば幸いである。

\section{文献}

1) T.L. Gardon: J. Paint Tech. 38, 43 (1966)

2) 渡辺信淳等：表面および界面 p.138 (共立出版㑣) M. Levine: Polym. Lett., 2, 915

関連する解説

○北原文雄：化学と工業,

32, 396 (1979)

○佐藤弘三：色材協会誌,

55, 399 (1982) 